\title{
北上山地·白山堂山, 矢越山両地域の若干のBlockstromについて
}

\section{松本繁樹}

北上・阿武隈雨山地には花崗岩質の岩石が広 大な面積を占めて分布しているが，これらの地 域には Blockstrom を初めと寸る各種の岩塊形 の認めら妃ことがある。この5ち2・3の地 域の岩塊形についてはすでに筆者自身簡単な 報告を行なったことがあるが(松本 1961, 1963， 1964a), 今回は同じく北上山地内の白山堂山, 矢越山の両地域について調査を行ない, それぞ れの地若干の Blockstrom を認めたので, こ こにその一部を報告し大方の御教示を仰ぐこと にした。

な抗ここにいう Blockstrom とは, 主に形態 上の定義にしたがったもので，巨大なBlockの 浅い谷状地での linearな集積形を指すものとす るが，それが形成機構・形成時代といった内面 的問題に触れる時にはな打幾つかの問題を残し ている。

\section{1 白山堂地域の Blockstrom}

北上山地の花崗岩類の5 万千既花菵閃緑岩体 そ呼ばれているものは,この山地の南部, 千厩 町付近から北西に細長く伸び，人首付近では人 首花南成緑岩体となって花巻市の東あたり李で 連続している。この報告で述べる2つの地域の 5ち 1つ, 白山堂山 (岩手県江刺市人首) は, こ

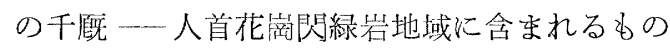
で女り, 他の 1 つ, 矢越山 (東撆井郡室根村) は, この千厩花崗閃緑岩の東に接した含石英モンゾ ニ岩からなっている(岩手県 1954)。

本節ではまず白山堂山地域の Blockstrom に ついて述べる。人首付近の花崗閃緑岩体は 4 〜 $6 \mathrm{~km}$ の幅で㴗涪南北方向に連続し, この帯状 部の中央やや東寄りに金成山(541)一笠根山一 (521) 一白山堂山 (475) と続く山稜部があり, 人首川 (北上川の一支流) の小横谷をはさんでさ らに阿茶山 (533) 亿と連続している。この屋根 筋の西側はかなり開析が進んで樹枝状谷が発達 して扣り，さらにその西方では新第三紀の安山 岩質凝灰岩および玉里層に覆われている(広川 ・吉田 1954)。な拈この花崗閃緑岩は灰白色を呈
し，一般に粗粒ないし中粒である。

白山堂山の Blockstrom はこの山の開析の進 んだ南斜面の浅い谷状部に位置するものであり (標高 380 220m), 今回の調查でその存在を確 認できたものは3つの場所分けられる(第1 図 $\mathrm{A}, \mathrm{B}, \mathrm{C}) 。 こ の う ち \mathrm{~B}$ 抽よびCの Blockstrom では現在採石が行なわれている。
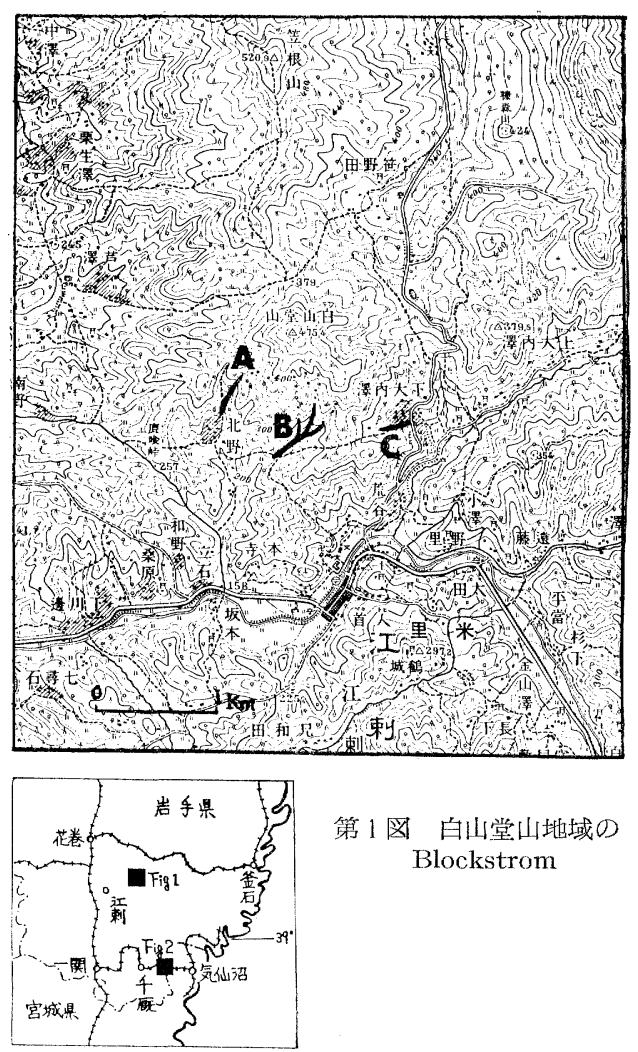

第1図 白山堂山地域の Blockstrom

まず最大の規模をもつ B B Blockstrom で は，その源流部は3つの支沢から成っているが， そのいずれにも小規模な Blockstrom が認めら れる。このうち中央の沢のものが最も大きく, 長さ $150 \mathrm{~m}$, 幅 6 10m, 傾斜 $8^{\circ} \sim 10^{\circ}$ であるの に対し, 東西両側の支沢では長さが幾分短かく $100 \mathrm{~m}$ 打よび $100 \mathrm{~m}$ 以下であって, ことに西側 のそれでは発達がかなり断続的である。Blockstrom 内には権木が密生するものの細粒物質 の洗脱はかなり進んでいて，いたる所で潜流音 
を耳にする。個個の Block は洞白色, 径 $1 \mathrm{~m}$ 前後の Wollsackform をなす。な技上方斜面 には Felsburg 状の岩体の存在することは殆ん どないが，斜面の一部では原位置で洗い出され た Wollsackblock の認められることがあって (写真 1)，かつての Block の供給源が周团の斜 面そのものであったことを推定させうる。

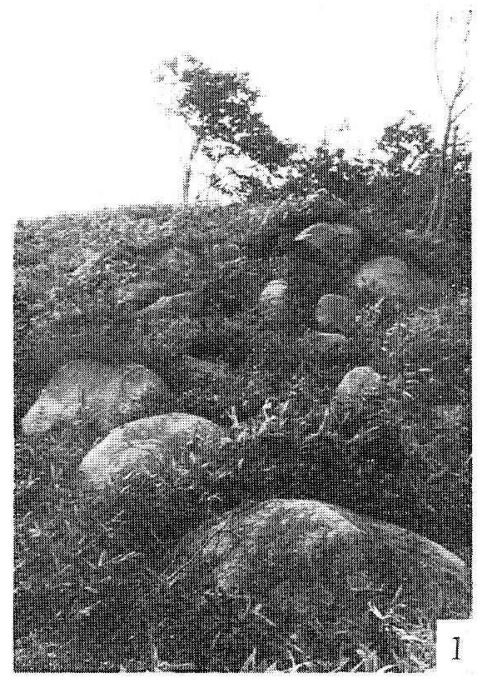

写真 1 白山堂山南斜面 (Blockstrom · B の上 方斜面）にみられる Wollsackblock

中央・東侧両支沢の合流点では Blockstrom の幅は $30 \mathrm{~m}$ となり, そこから $8^{\circ} \sim 10^{\circ}$ の傾斜 で約 $150 \mathrm{~m}$ 洼ど下ると灌木を切り開いた緩傾斜 地に出るがこここでの Blockstrom は植生㧍よ び組䊉物所を完金には欠いていないものの，横 断面中央部のやや盛り上った典型的なBlock の充填形を示している (写真 2)。Blockstrom はここから再び灌木に覆われ, 幅 $20 \mathrm{~m}$ 前後, 傾斜 $5^{\circ} \sim 10^{\circ}$ で若干の蛇行圭呈して約 $250 \mathrm{~m}$ 注

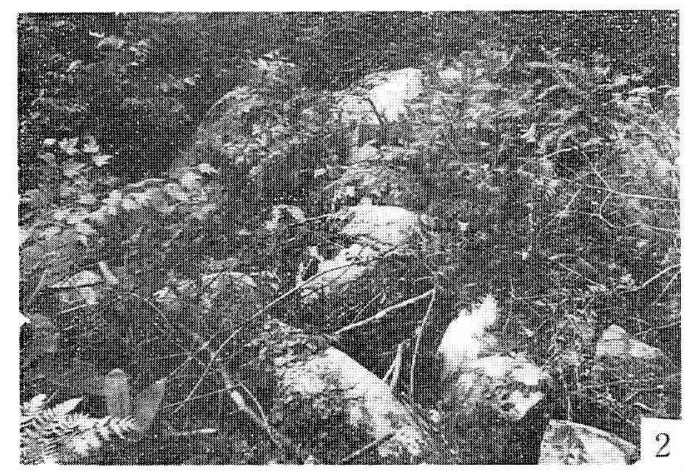

写真 2 Blockstrom. B O中流部
ぞ連綂し，水田の現わ机地点で急に終ってい る。Block は径 $1 \mathrm{~m}$ 削後であるが，上流部に 比べてやや巨碩が多く, 最大 $4 \times 3 \times 2 \mathrm{~m}$ 程度 のものを含导。末端の採石断面で文ると，表面 には密な植生を許してはいるものの，その下部 は厚さ $4 \mathrm{~m}$ 以上の人小雑多な Block の集積塊 でまり，Block 間の畔粒物質は表層に近い部 分を除けば殆んど完全に洗脱されてし安ってい る。な扮源流部からここまでの Blockstrom の 長さは $500 \mathrm{~m}$ 前後に達するものとみられる。

白山堂山の南西斜面を北野部落に下るAの Blockstrom は, つぎの 2 つの部分からなって いる。すなおちその上流部は幅 10〜20m, 長 さ約 $250 \mathrm{~m}$, 傾斜 $5^{\circ} \sim 10^{\circ}$ で一般に灌木に覆わ れ，多の横断面では山状に盛り上った Blockの 景景をる集積形を示すのに対し(写真 3)，その

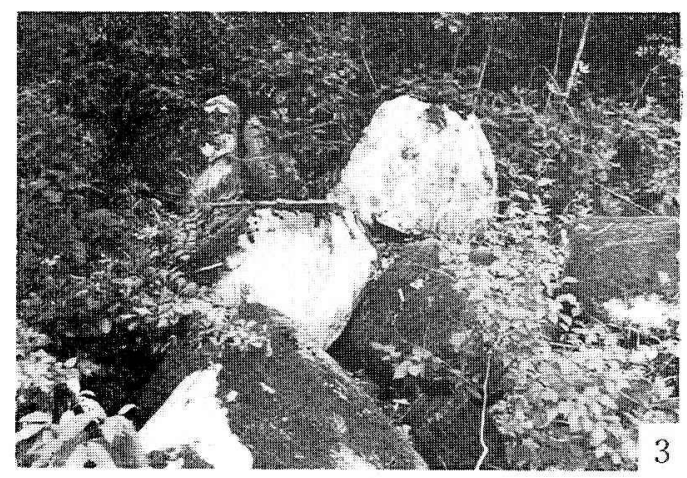

写真 3 Blockstrom - A の上流部

Wollsackblock の累㬌たる集積塊 なす

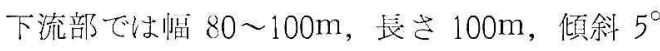
の小䙺模な净状地恻の広がり (畑地) となり，を の中に Block の䫓半部が多数露出して, いわ ぼ潜在的な Blockstrom とでも表現すべき形態

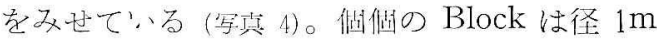

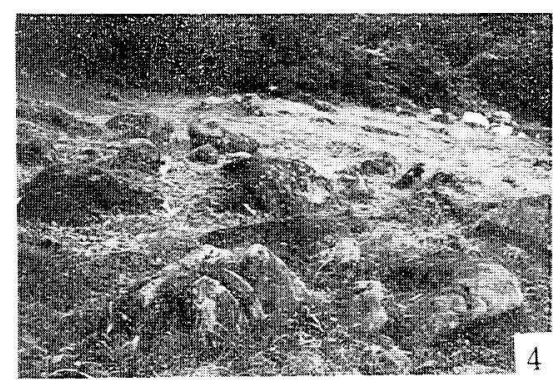

写真 4 Blockstrom の下流部 扇状地性の広がりの中に Block の頭 半部力゙多数露出している 
前後の Wollsackform でもり, 最大級のものは $4 \times 3 \times 2 \mathrm{~m}$ 程度である。なおこの地の源流部で 为 Felsburg 状の罟体は殆んぞ珰められない。 下大内沢部落に下る C の Blockstrom は前二 者に比べてやや規模が小さく，全体として約 $250 \mathrm{~m}$ の長さで岁るが，ての上限付近で現在採 石が行なわれている。この採石断面を見ると表 面は密な灌木林で鳆われていても，それ以下は 細粒質マトリックスの殆んど洗脱された曆さ6 $\mathrm{m}$ 以上のBlock の集積塊であり，その内部には かなり小さなBlock 本でを含んでいる(写真5)。

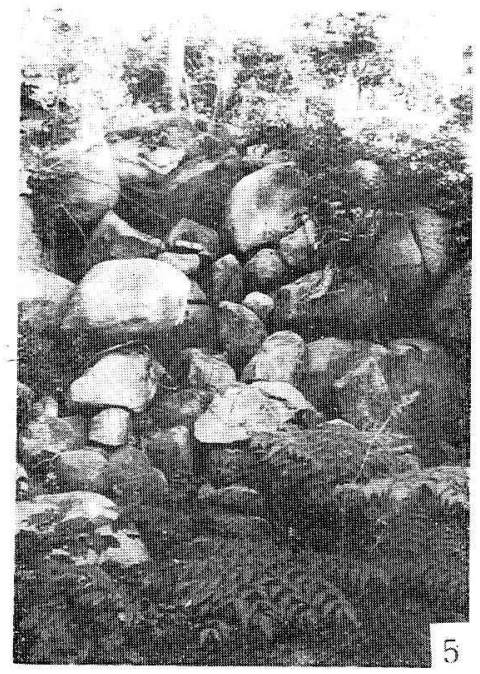

写真 5 Blockstrom・C に抄ける採石断面 大小雑多な Block の集積塊であり， 細粒質マトリックスは表層を除き殆ん ぼ完全に洗脱されている

Blockstrom の上半は幅 $10 \mathrm{~m}$ 前後, 傾斜 $10^{\circ}$ で $150 \mathrm{~m}$ 注ど続き，そこから小规模な扇状地性の 広がりに移行する。この扇状地性の㕕がりの中 にもBlock の頭半部が多数露出するが，先の Blockstrom はな招もこの広がりの南寄りを 10m の幅をもって 100m ほど連綍している。 この Blockstromの末端は道路付近で終り，そ こから人首川の支流・大内沢川に対しては急崖 をなして下っている。

なお以上に述べた白漟山地域および以下に 述べる矢越山地域では, 数多くの露頭で厚さ数 $\mathrm{m}$ 以上にの菭る基盤の深層風化断面を見ること ができるが，これらの風化層準には径数 $10 \mathrm{~cm}$ から $2 \cdot 3 \mathrm{~m}$ に过達する Wollsack 状の風化核 を数多く含んでいて (写真 6), Blockstromに

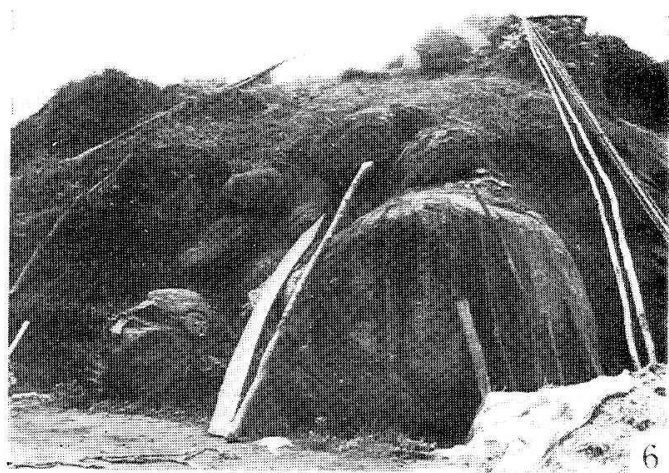

写真 6 基盤の深層風化断面（矢越山柄构田） Wollsack 状の core stone $か ;$ 多数諗 められる

対する Block の供給源がこういった風化層準 揖よび一部は Felsburg 状の岩体（とくに矢越山 地域)であったことを推察させる。

\section{2 矢越山地域の Blockstrom}

矢越山 $(519.6 \mathrm{~m})$ は大船渡線 矢越駅南少約 $3 \mathrm{~km}$ に要り，緻密堅硬な中粒質の含石英モン ゾニ岩から成る。このモンゾニ岩は矢越山西方 $3 \mathrm{~km}$ 付近で千碳花雕閃緑岩に接するが，この 両岩の侵蝕に対する差はかなり明瞭で，花南閃 緑岩地域では充分に樹枝状開析が進んでいるの に対し，モンゾニ岩地域では開析が相対的に微 弱で充分な山容を保っている。

矢越山地域ではその北東・南西・北西斜面の

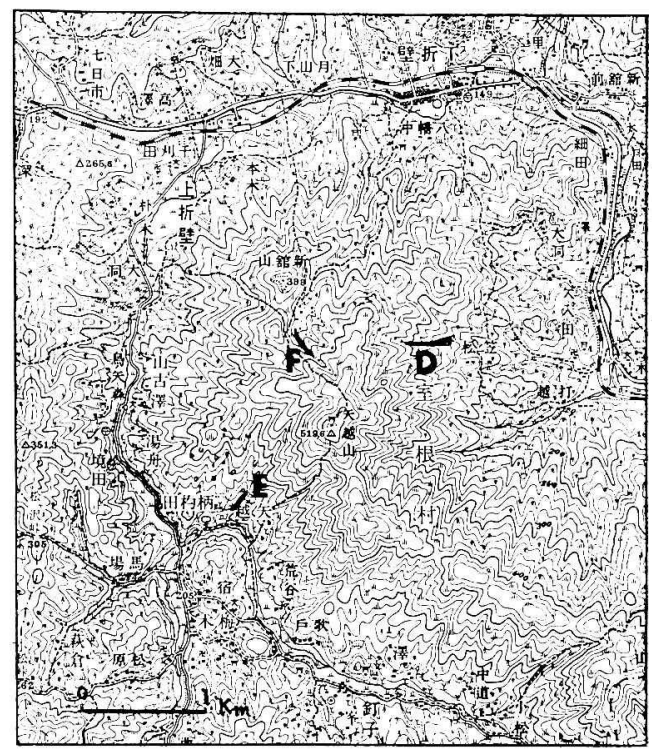

第 2 図 矢越山地域の Blockstrom 
3 カ所に Blockstrom を認るたが (標高約 400〜 200m) (第2図 D, E, F)，この他にも小規模な子 のはな打幾つか存在しているものと思われる。

矢越山頂から北方に伸びる山稜の束側斜面に は, 暗灰色の Felsburg 状の大岩体之斜面の風 化層準から洗い出された風化核とが多数存在 し，之の下方には奥の広い馬䠙形の谷が開けて いて，その中流以下にDの Blockstrom が存 在可当 (写真 7)。この Blockstrom は長さ約

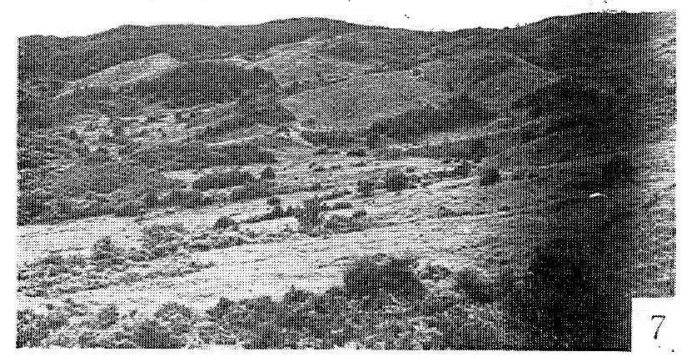

写真 7 Blockstrom・D の発達する公状地 㕕い谷状地の中央から左下方に向け て Dの Blockstrom が始まっている (灌木林の生育している部分)

$200 \mathrm{~m}$ ，幅は $10 \mathrm{~m}$ 前後から未端付近では最大 $50 \mathrm{~m}$ に達し，傾斜は上部 $150 \mathrm{~m}$ 間で $5^{\circ} \sim 6^{\circ}$, 下部 $50 \mathrm{~m}$ 閒ではやや急で $10^{\circ}$ 程度となる。表

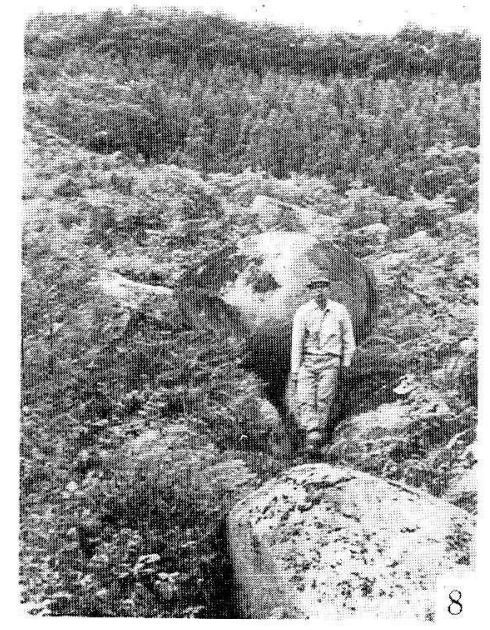

写真 8 Blockstrom·D の中流部
面には笽や小灌木などの植生を許するのの, 中 心部では細粒質マトリックスの洗脱はかなり進 えでいて，Block 間にはいたる所小空洞が形成 されている(写真 8)。個個の Block は一般に径 1〜2m，下流部にはやや巨砂が多く最大は $4 \times$ $3 \times 3 \mathrm{~m}$ 程度である。Block の形態は典型的な Wollsackform から殆九ど角碟に近いものなで さ交ざななるのを含むが (角をもつ Block のかな りの部分は Wollsack 形成後の裂開である)，全体と してみると先述した向山堂山の場合よりも丸味 の程度が幾分弱い。この形態上のわずかな差は 緻密堅硬な中粒質の含石英モンゾニ岩という岩 質の影響掞よび一部はなた Block 供給源とし ての Felsburg 状の岩体の存在によるものと考 えられる。この Blockstrom の末端は一部は 急傾斜をなして水四に, 一部は下折壁——打越 間の道路を越えて下方の息な谷に続くが，乙れ 以下は密な植生のため明らかでない。な掞この Blockstrom のすぐ南の小谷には，外観上土石 流的とでる表現すべき角ばった Block の集積 塊が女るが，こ机については今回は調查を行な い光なかった1。

とこるでこういった Block の充填形は，を れが原位置での基盤の残留風化物では为りえな い，換官すれば基盤岩とは不整合に上方斜面か ら流動してきたもので弯ることは，上に述べた Blockstrom の形態上の特徵から推察できるこ とでめるが，事実笠松部落近くの小山脚末端の 路頭では，基盤の風化層上に載る厚さ2 3 3 の 巨磂を含さ啋層の存在を観察できるし(写真9)，

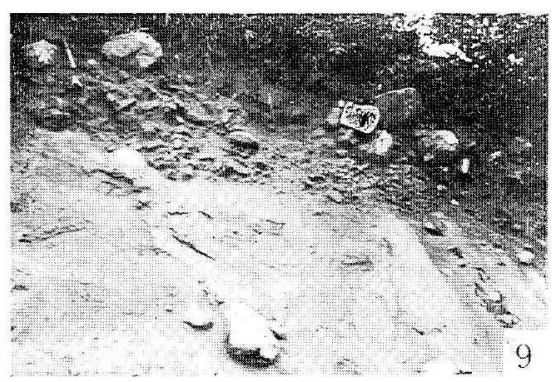

写真 9 基盤の風化層上に載る砂硶層（矢越 山北東笠松部落)

别の露頭ではこういった碩層の下底に傾斜にそ った引きずれの跡らしきものさえ認められるこ

1）この土石流的集積塊は急な側壁をもつ小谷中にあって，「状に盛り上った横断面を呈し，表面は灌木 に覆われている. Block は径数 $\mathrm{cm}$ から 1〜2m まで大小雑多で角啋質のものが多く, Block 間には 表層, 内部を問わず充分な細粒質マトリックスを有している. 
とが禹る。

矢越山南西地域では筆者は柄构田一矢越部落 間に 1 条のBlockstrom 孝認めたが(第2図E)， この上方の山腹斜面には Felsburg 状の巨岩体 と巨大 Block とが数多く存在している。 Eの Block-strom は表面を直径数 $10 \mathrm{~cm}$ の㕕葉樹 を含告厚い:灌木に䨱われ，しか子それが隣接す る水田面よりも 1.5〜数 $\mathrm{m}$ \& mound 状飞盛 り上っているため，一見しただけでは站なる小 山脚末端と見䛊る恐れが恋るが，内部に立り 入って見るとその密な植生にもかかわらず， Block 間にはかなりの空洞があり，それを通し て Blockの累累たる充填状態を見ることがで きる。Blockstrom の長さは 120〜130m（ただ 乙上流仗未調查), 幅 $10 \sim 20 \mathrm{~m}$, 厚さ数 $\mathrm{m}$ 以上, 倾斜 $3^{\circ} \sim 6^{\circ}$ で, 個個の Block は径 $1 \mathrm{~m}$ 前後, 大きいるのは $2 \mathrm{~m}$ ないしそれ以上に拉よび，形 態は一般にWollsack, ただしかなりの触の るものまでを含んでいる。この Blockstromの 末端は柄构田一荒谷間の道路直下で念に終り,

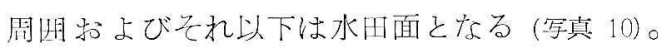
な沶この地域にはこの Blockstrom 以外にも山 脚の末端部に小規模な mound 状の盛り上り地 形があって, 同様な Block の集積塊を成して いるし，その汪か畑地・水四中にも巨大な Block が散在している。

5 万分の 1 地形図の矢越仙北束斜面には, 新 館山 (399m) との間に3 条の著しい政倠記号が
印されている2゙。しかし著者が今回碓㴓しえた

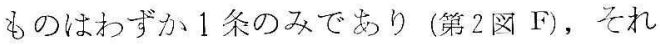
とても外面的形態に関する限り Blockstrom といらほどの印象を受けるものではない。すな わちここには幅 30〜 50m, 長さ $150 \mathrm{~m}$, 傾斜 $5^{\circ} \sim 7^{\circ}$ の浅い谷状地があって, 表面は小灌木 を混じえた草地を成しているが，その中にかな りの数の Wollsackblock がその頙半部を露出 させている。これが潜在的 Blockstrom にあ たるものであるうことは殆んど疑い得ないが， 植生が密なためその规模については明らかでな い。この末端から北に向う袋状の浅い谷底には (䝨斜 $5^{\circ}$ 前後), 開拓農家に上る牧草地・水田が 開かれているが，これら耕地にもいたる所 Wollsackblock の頭半部が露出していて, 先 の潜在的 Blockstrom の下方延長にあたるもの と考えられる。

\section{3 洘察}

以上著者は白山学山，矢越山雨地域の Blockstrom について記述してきたが，本節ではそ れらの成因に関して若下の考察を行なって文 たい。

上述の Blockstrom はいずれも山地を刻む浅 い谷状部の中流から末端にかけて linearな発 達を示すが (標高䄪 400 20cm)，その傾斜はか なり緩く一般に 5゚〜10にすぎないこれら Blockstrom の术端は，Block を含む緩い小扇

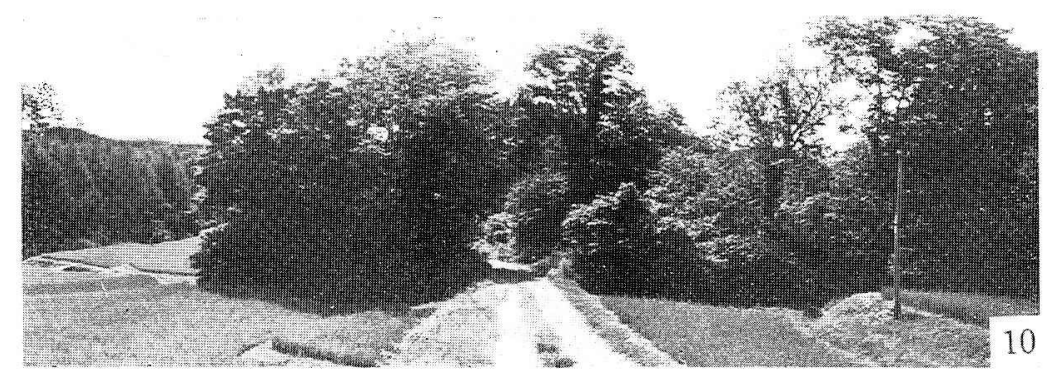

写真 10: Blockstrom・E の末站

Blockstrom（樹林地内）は周囲の水田面よりも盛り上って予り，その末端は道路近くで 急に終っている

2)こういった散岩祀号が小起伏の花崗岩質山地内に衿められる場合には、それが Blockstrom である可 能性はかなり高く、实際それがまた Blockstrom を探す有力な于がかりてなるが，逆に同じううな地 形唒置と散岩部号が印されていても. 現地に行くと別種の形態であったり，その後の植物の成長や人

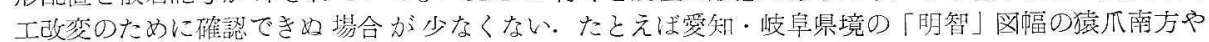

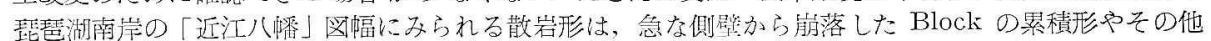
の地形を袁現したものであって，等者の述べる Blockstrom とは質を異にしている，なお矢越山の南 で同じ「千廐」図幅中の大森山南涂面の散岩形もこれまたBlockstrom ではなく，急な側壁 $\left(30^{\circ}\right.$ 前 後）から崩落した角ばった Block のBlockhalde 的集積形である・ただしこの地域の岩石は堅硬緻 管な粘板岩〜石灰岩からなっている。 
状地性の広がりに移行し，その下流で水田面に 接する場合と直接水田面化終る場合とがある が，白山堂山・C の Blockstrom に代表され るようにそれらは一般に現在の基準面に協和し ていない。

以上の形態上の特微と現在の基準面に対する 不協和性，さらに細かくは大樹を含む植生から 考えて，これらの Blockstrom は現在生成扰よ び流動しているものではなく，少なくともその 主体的営力は過去のもので女ったことを示して いる。上記の Blockstrom は一般に灌木の生育 を許すに充分なマトリックスを含んでいるが， この細粒物質は実際には表層に近い上部に存在 するのみで，それ以下では下底を流下する小潜 流によって汪浣完に洗脱されてしまってい る。な招 Blockstrom の下方に続く小扇状地性 の公がりは，一部は未だ洗脱の進まない潜在的 Blockstrom にあたっているが，同時にそれは 上方斜面から運び出される細粒物質の集積場所 に㚣たっていたことであろう。

つぎに Block の流動機構について考える。 上述の Blockstrom では一般に径 1 数 m の Block が幅 10 数 $10 \mathrm{~m}$, 長さ 150 - 500m の 帯波の広がりを占め, 若干の蛇行を呈して蜿蜿 と連続していること, 多くはコンヴェクスな横 断面をるち, 中には周囲の水田面上り 1.5 数 $\mathrm{m}$ も mound 状洫り上っていること,な ぞについてはすでに述べたが，これらの形態上 の特徴は Blockstrom 中の Block が直下の基 盤岩から洗い出されたものではなく, 換言すれ ば in situ での風化残留物では岀りえず，上方 斜面から流動してきたものであることを示する のであり，先の基盤の風化層上に載る巨礫賸の 存在もこのこと証拠づけているものと思われ る。そこでこの場合の Block の流動機構につ いてであるが，もちろん異常な豪雨による土石 流的発生の可能性を否定できないにしても, 谷 頭付近の狭小な集水面積では充分に解釈できな い場合が多いし，また周囲の斜面からの崩落に よる集積説も横断面に扣忛るコンヴェクスは盛 り上りを説明することができない。同じことは 著者自身が先に報告た北上・阿武隈の若干の場 所にも認められることであり, これらの地域で は何らかの特殊の形式の流動が過去㴡存在した あのと考兄られる。そこで問題にこういった特 殊な形式の流動が，ヨーロッパや北アメリカで
この種の形態形成に寄与したと考兄られている solifluction (Wilhelmy 1958, Smith 1949, 1953) と 同じものかどうかという点である。北海道およ び東北地方についての最終水期の周氷河現象 は, 鈴木 $(1960,1962,1966)$ や若生 $(1963,1964)$ に よってその証拠が論じられているし，末た中国 地方では今村外治 (1962) が, 岩海の形式には 現在よりも寒冷な気候環境が過去にあったと仮 定する方が好都合であると述べている。したが って箨者の論じている地域について周氷河環境 を想定することは必らずしも蓋然性の低いこ とではないし，少なくともこういった大規模な 流動には，その前提条件として植生を欠くよ らな環境が必須であったろう。先の基盤の風化

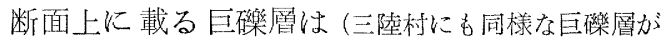
存在する(松本1962)），こ5いった流動の一部を 示していると考兄らるが，ただこれがの solifluction の確証であるかどうかという点代 問題が残る。この地域のごとく最終氷期の周水 河現象の限界に近いと推定される所では, Blockstrom の形成に気候条件のみが単独に作 用したと考えるのは適当でなく，この気候条件 と共に，植生の欠如，流動を容易にする斜面形， 流動に先立つBlock扣よび細粒物質の潜在的準 備，といった諸条件が相互にう李くかみ合い重 なり合った場合にのみ Blockstrom としての発 生をみる，と考光るべきであろう。

ここで重要なことは Blockstrom が細粒質マ トリックスを含んでいることで，こういった細 粒物質がひとたび充分な水分を含む時には巨大 な Block の搬出に刘して一種の lubricant と なり，Blockに浮力を与光て大規模な流動をひ き起こすと考宇られることで (Roy 1952, Beaty 1963), 本地域の Blockstrom 无恐らくこうい った Schlamm-Blockstrom の流動形式をとっ たことであるう。

つぎに Blockbildung の問題がある。白山堂 山地域での Block は粗粒ないし中粒の花䖒閃 緑岩からなり，一般に丸味の岁るWollsackform をなすこと，上部斜面には Felsburg 状 の岩体は殆んど認められないこと, これに対し て中粒の含石英モンゾニ岩から成る矢越山地域 の Block は典型的な Wollsackform から角ば ったものまでを含み, 前者に比べてやや丸味の 程度の弱いものが多いこと，上部斜面にはしば しば巨岩体の存在していること,さらに両地域 
には共通していたる所基盤岩の深層風化断面が 存在し, その中に多数の core stone が認めら れることなどについてはすでに述べた。これ らの事実扣よび基盤の深層風化断面に載る巨䃯 層の存在とから, 両地域ではその流動に先立。 て深層風化の進展した時期が焉って，そこで Block や Felsburg の潜在的生産が行なわれ， その後の気候变化その他の原因に上る植生の破 壞がこれらの core sone や Felsburg 状の岩 体を露出させ，同時に Blockstrom としての流 動を菍き起こしたものと考えられる。したがっ て Block の供給源は白山堂山地域では集水域 の斜面そのものであり，矢越山地域ではそれに 加えて Felsburg 状の岩体からのものまでを含 んでいたことになる。な折両地域の Block に 若干形態上の差があるのは，一部はこういった 供給源の違いによるもので岀ろらが，李た一部 は両地域の岩質の差にるものと考光られる。と ころで Blockbildung に Frostsprengung 説, 深層風化説の対立の女ることは前回の報告にす でに述べたが (松本 1963，1964b), 最近 Rother はドイッの Talschwazwald の Blockstrom の 調査をもとに，粗粒な黒雲母花崗岩からは巨大 な Wollsackblock が, 中・細粒の両雲母花落 岩からは角ばった小 Block が形成されるとし， Block の形態上の差は気候の差よりもむしろ 岩石の粒度や構造の違いに関係のあることを報 告している (Rother 1965)。

Block の形態上の美がある程度まで岩質に よるものであろうことは筆者自身すでに前回に 述べたが (松本1964b)，わが国のごとく気候上の 制約が熱带・寒冷いずれについても決定的でな い地域に岀っては，岩質土の制約は気候上の制 約と並んで相対的に重要な意味をもってくる筈 であり，それがまた Block の形態に微妙に反 映されるものと思われる。

な打以上の考察の中には本質的には蓋然率の 問題を含んで㧍り，今後の充分な証拠固めが必 要で女る。

\section{4 まとめ}

以上筆者は北上山地の白山堂山括よび矢越山 両地域の Blockstrom について論じてきたが， それらの形態拈よび成因についての考察の結果 を要約するとつぎのようになる。

（1）白山堂山地域は粗・中粒の花崗閃緑
岩, 矢越山地域では中粒の 含石英モンゾニ岩 と岩質上の相違は存在するものの, 両地域の Blockstrom はいずれも山麓化近い浅い谷状部 に出って, 幅 10〜数 $10 \mathrm{~m}$, 長さ 150〜 500m, 傾斜 $5^{\circ} \sim 10^{\circ}$ の linear な発達を示して扣り, 表面は一般に灌木に覆われている。個個の Block は径 1 数 $\mathrm{m}$ で一般に Wollsackform を旺するが，矢越山地域では丸味の程度の幾分 弱いものが多い。

（2a）両地域の Blockstrom はいずれも化石 化して扮り，現在は細粒質マトリックスの洗脱 作用のみが行なわれている。

(2b) 上記の Blockstrom は in situ での 風化残留物ではなく, 細粒質マトリックスを lubricant とした Schlamm-Blockstrom 状 の流動によって形成されたものとみられるが， こういった形式の流動には気候条件と共に，植 生の久如, 流動を容易にする斜面形, Block と 細粒物質の潜在的準備, といった諸条件が相互 にうまく重なり岕っていたと考えられる。

（2c）両地域にはこの流動に先立って広沉に 深層風化の進展した時期が存在したが, Block やFelsburg の潜在的生産はこの中で行なわれ ていた。な扣雨地域の Block に見られる若干 の形態上の差は，主として岩質の違いによるも のと思われる。

(1966.6.30 受理)

最後に日頃御指莩いただいている能，西村両先生 に厚く御礼申し上げる.

\section{文献}

Beaty, C. B. (1963): Origin of Alluvial Fans White Mountains, California and Nevada Ann. Assoc. Amer. Geogr. 53 516 535

台川 治·吉田 尚 (1954)：5万分の1 地望図幅 「人首」同説明書 地質調查所

今村外治 (1963)：西中国地方の岩海 (Felsenmeer) の数例について 広島大学地学研究報告 12254 $\sim 275$

岩手県土木部（1954）：10万分の1岩手県地質図

松本繁樹 (1961)：北上山地・三陸村の岩塊流 地 理科学 2 34 39

松本繁樹 (1963)：阿武隈山地・花崗岩類地域の岩 塊形東北地理 $1599 \sim 106$

Matsumoto, S. (1964a): Landforms of Accumulated Boulders in the Abukuma and Kitakami Mountainlands Sci, Rep. Tohoku Univ. 7th Ser. (Geogr.) 13 201 214 
松本繁樹 $(1964$ b)：奈良県神野山・鍋倉の Blockströme 静岡大学教育学部研究報告 (自然科学 篇) $15 \quad 113 \sim 120$

Rother, K. (1965) : Ein Beitrag zum Blockmeerproblem Zeitschr. f. Geomorph. 9320 $\sim 331$

Roy, C. J. and Hussey, K.M. (1952): MassWasting on Table Mountain, Fremond County, Colorado Amer. Jour. Sci. 250 35 45

Smith. H. T. U. (1949): Pariglacial Features in the Driftless Area of Southern Wisconsin Jour. Geol. 57 196 215

Smith, H.T.U. (1953) : The Hickory Run Boulder Field, Carbon County, Pennsylvania Amer. Jour. Sci. 251 625 642

\author{
鈴木秀夫（1960）：北海道北部の周氷河地形 地理 \\ 評 $33625 \sim 628$ \\ 鈴木香夫 (1962)：低位周水河現象の南限と最終水 \\ 期の気候区界 地理評 $35 \quad 67 \sim 76$ \\ 鈴木秀夫（1966）：日本にお污る凍結融解交代日数 \\ の分布 地理評 $39 \quad 267 \sim 270$ \\ Wako, T. (1963): Valley Features along the \\ Sarugaishi River-A Note on Block Field, \\ Cryopediment, and Relict Soil in the Ki- \\ takami Mountainland Sci. Rep. Tohoku \\ Univ. 7th Ser. (Geogr.) 12 53 69 \\ 若生達夫（1964）：東北日本における地形面と赤色 \\ 風化款との関係 第四紀研究 3 197〜211 \\ Wilhelmy', H. (1958): Klmamorphologie der \\ Massengesteine Georg Westermann
}

\section{Some Blockströme at Shirayamadôyama and Yagoshiyama in the Kitakami Mountainland}

\section{Shigeki MATSUMOTO}

The writer found some Blockströme in the valley flat (altitude of 400-200 meters) at Shirayamadôyama (granodioritic) and Yagoshiyama (monzonitic) in the Kitakami Mountainland. In these areas Blockströme are 150-500 meters along and 10-60 wide with a depth of several meters, and gradients of these Blockströme are 5-10 degrees on an average. Blocks in Blockströme are 1-4 meters in diameter and have the shape of "Wollsack", but a considerable part of these blocks has the sub-angular form in Yagoshiyama area.

In all Blockströme in these areas, the present movement is unrecognizable and the water at the bottom of a Blockstrom has a tendency to wash away interstitial earthy material. It seems that these blocks in Blockströme are not the core stones out of the deep-weathered bed rock in situ, but were transported by means of mass movement from the upper slopes and Felsburgen.

As to the development of Blockströme in these areas, three stages are recognized: the first stage is a period of extensive sub-surface rock weathering whose pattern is controlled by structural conditions: the second stage is a period of the exhumation of core stones and Felsburgen (by removal of the fine-grained products of rock decay) and the transport of blocks by means of mass movement: the thrid stage is a period in which interstitial earthy material was washed away. 